\title{
Value Above Reference Range
}

National Cancer Institute

\section{Source}

National Cancer Institute. Value Above Reference Range. NCI Thesaurus. Code C78800.

Reported values above the typical or expected range. 